Article

\title{
Exploring Science-Policy Interactions in a Technical Policy Field: Climate Change and Flood Risk Management in Austria, Southern Germany, and Switzerland
}

\author{
Ralf Nordbeck $^{1}\left(\mathbb{D}\right.$, Lukas Löschner ${ }^{2, *}$, Melani Pelaez Jara ${ }^{3}$ and Michael Pregernig $^{3}$ \\ 1 Institute of Forest, Environmental, and Natural Resource Policy, \\ University of Natural Resources and Life Sciences, Vienna, 1180 Vienna, Austria \\ 2 Institute of Spatial Planning, Environmental Planning and Land Rearrangement, \\ University of Natural Resources and Life Sciences, Vienna, 1180 Vienna, Austria \\ 3 Institute of Environmental Social Sciences and Geography, Albert-Ludwigs-University Freiburg, \\ 79085 Freiburg, Germany \\ * Correspondence: lukas.loeschner@boku.ac.at
}

Received: 28 June 2019; Accepted: 7 August 2019; Published: 13 August 2019

\begin{abstract}
This paper analyses the science-policy interactions in the field of flood risk governance against the background of climate change. By the example of three neighbouring Alpine regions (Switzerland, Southern Germany and Austria), the study strives to shed further light on how flood risk governance regimes embrace the possible impacts of climate change. It builds on the assumption that flood risk management, as a 'technical' policy field, is strongly influenced by scientific evidence and that differences in how countries incorporate climate change can be explained by the way science and policy are brought together in the respective national arenas. We structure the empirical analysis along three dimensions: (i) dynamics of knowledge creation; (ii) institutionalization of the science-policy interface; and (iii) pathways of influence of expertise on policy development. We find that there is a mixed, though increasing influence of climate change on flood risk governance in the three selected Alpine regions. Climate adaptation has become an important issue of flood policy in all three study areas, and this shift has been strongly supported by evidence-based arguments.
\end{abstract}

Keywords: science-policy interface; flood risk management; climate change; adaptation

\section{Introduction}

The influence of climate change on future flood risk in Europe is still highly debated. Analyses of past trends show no clear patterns of robust and ubiquitous climate-driven change in flood magnitude and frequency of high discharge in European rivers during the last decades. Rather in contrast, there are strong regional and sub-regional variations in the observed trends [1]. Similarly, the results of climate models are uncertain regarding the prediction of future changes in frequency and magnitude of floods, inter alia, because of uncertain information on phenomena such as an increased spatio-temporal variability of precipitation and changes in extreme rainfall events [1,2]. This provides extensive challenges for policy-makers in charge of flood risk management and climate change adaptation "because it is naive to expect availability of trustworthy quantitative projections of future flood hazard" any time soon [3] (p. 1). Dealing with these highly uncertain changes requires new approaches to policy-making that support the move from resistance-based strategies to more resilience-oriented approaches. While resistance-based approaches can provide effective protection and minimize costs up to certain design floods, they "do not cope well with uncertainty" [4] (p. 291). Resilience-based 
strategies, on the other hand, embrace adaptability and flexibility as a means to respond to the climate-induced increase in flood discharge and thus better cope with the shocks and stresses of (extreme) flood events [5-7].

Climate adaptation policies emerge from the interplay of a varied set of actors, including policy-makers, scientists, engineers, and many other stakeholders, leading to numerous ambiguities, since successful policy-making is not about finding the objective truth in a scientific sense, but about finding a balance between different positions. While the interlinking between climate chance and flood risks has been widely studied in the field of engineering and the natural sciences, there are only a few studies on the influence of climate change on flood risk governance. In a European context, the project STAR-FLOOD [8] delved into this question. In a comparative study of six EU countries, the project found that climate change as a risk driver has only a fairly modest impact on flood risk governance overall [9]. For five of the six countries, the authors found that the discourse on climate change tends to stabilize existing governance arrangements with their emphasis on prevention and defense: In England, the climate adaptation discourse influenced the broader discussions on the financial sustainability and cost-efficiency of the current flood risk governance, yet the overarching risk approach did not fundamentally alter [10]. In Poland, the influence of climate change has been limited, both because climate change projections are considered uncertain for Poland and because of lacking political and societal support for policy changes [11]. A mentionable exception is Sweden where climate change has played a pivotal role in the observed shift of flood risk governance [12].

This paper strives to shed further light on the question of how flood risk governance regimes embrace the possible impacts of climate change. Thereby, we build on the assumption that flood risk governance, being quite a 'technical' policy field, is strongly influenced by scientific evidence and that differences in how countries incorporate climate change might be explained by the way science and policy are brought together in the respective national arenas. Against this background, we delve into the following analytical questions: What are the implications of scientific evidence on climate change for flood risk governance? How do policy-makers deal with those high degrees of uncertainty, both in terms of causal drivers and impacts? What is the role of science and expertise in this technical policy field? These are the questions we are going to explore in this paper. Empirically, we draw on a comparative case study of flood risk management in the context of climate change in three Alpine regions: Austria, Southern Germany, and Switzerland.

The remainder of this paper is structured as follows: Section 2 summarizes the state of science-policy research and presents the analytical dimensions along which we explore the science-policy interactions in the field of flood risk governance. Section 3 presents the empirical findings for the three study regions Austria, (Southern) Germany and Switzerland. Finally, in Section 4 we discuss our main findings based on the cross-case comparison.

\section{State of the Research and Own Conceptual Framework}

Flood risk management is a highly complex and technical policy domain. It entails understanding the underlying factors that drive flood risks, including the complex drivers related to land use changes, socioeconomic developments, and climate change [13]. Further, it requires modelling these dynamics to assess changes in flood risk [14], and devising instruments to mitigate those risks-from designing and constructing flood defenses and other technical infrastructure to developing and adjusting land use plans and building codes [15]. Consequently, flood risk governance-understood as the structures and processes in which public and private actions and resources are coordinated for solving collective problems [16] - is expected to be informed by an evidence-based approach. This expectation has been partly substantiated by research in the abovementioned STAR-FLOOD project. As part of this project, Wiering et al. [9] provided a typology of varieties of flood risk governance in Europe. For the six countries studied in detail, the authors found national approaches to flood risks and their governance to be marked by a dominance of public actors (especially in the Netherlands, Poland, France, and Belgium) as well as central authorities with strong legal powers (especially in Poland and France). Similarly, 
Liefferink et al. [17] reported on the strong and powerful role of expertise and expert bodies (especially in the Netherland and Poland), an observation confirmed by other authors, like Lange and Garrelts [18] for Germany, or Mostert et al. [19] and Bergsma [20] for the Netherlands.

The literature on flood risk governance is still quite fragmented [21,22], and there are only a few studies explicitly focusing on the question of what role science and expertise play therein. There is more research on science-policy interactions in the broader field of water governance; however, also these studies have a strong bias towards more instrumental, managerial perspectives. Many of those studies start from the observation—or rather assumption—that there is a "gap" between science, on the one hand, and management or policy, on the other hand. This is seen as a problem because, as Timmerman and Langaas argue, "[c]onsistent and relevant information on the status of water systems is indispensable for rational and cost-effective water management" [23] (p. 177). Similarly, Xu and Tung postulate that "[d]ecision-making in water management requires the delivery of accurate scientific information" [24] (p. 535). As these two examples indicate, studies often build on a rather simple, linear model of "information transfer" and a quite a-political, if not to say "naïve", understanding of the policy process (for a critique of the linear model in general, cf. Refs. [25,26]).

Recent studies have overcome some of this linearity in that they do not just call for the more effective transfer of information from science to management or policy, but rather first try to better understand the context in which management or policy decisions are taken. For example, Leskens et al. investigate how information from flood models "is exchanged among participants in flood disaster organizations and how this exchange affects the use of modelling information" [27] (p. 53). Similarly, Höllermann and Evers analyses "how practitioners perceive and handle uncertainties in their daily decision-making routines at the knowledge/decision interface and how they evaluate and integrate uncertainty information into their decision-making" [28] (p. 9).

All of the above-mentioned studies focus on the micro level of individual decision-makers, mapping for example the information that managers have available, describing the organizational contexts in which they operate, and assessing the decision support tools on which they can draw similarly [29-32]. In contrast to that, there are only few studies that look at the macro level and take a more policy-oriented perspective. In a European context, those policy-oriented studies have often been developed around the EU Floods Directive (2007/60/EC) and its implementation in Member States. Empirically, most of those studies took a rather narrow perspective by looking at the role of participation as one of the key governance principles enshrined in the Directive (e.g., Refs. [33,34] for Germany; Ref. [35] for the UK; Ref. [36] for Sweden).

A more comprehensive assessment of flood risk governance arrangements (FRGAs) was provided by the STAR-FLOOD project: The project was comparative in scope, analyzing and contrasting FRGAs in six European countries. It went beyond the EU Floods Directive and its national implementation by taking a more long-term perspective, analyzing FRGA dynamics from the 1970s up to the present, thus, trying to explain stability and change in the sector [17]. In addition to that, similar to our paper, STAR-FLOOD engaged in the question of whether and how climate change might have an impact on FRGAs. On that topic, Wiering et al. [9] reported that in five of the six countries studied, discussions on climate change showed a rather modest impact on national risk approaches; only in Sweden, climate change was seen to play a key role in observed shifts of risk governance.

Our paper deals with some of the questions also addressed in STAR-FLOOD, however, we strive to not only look at the macro level of national arenas but we also incorporate meso-level structures and dynamics. For that, we take an explicit, more fine-grained look at the role of science and expertise in flood risk governance, a perspective that is missing in all more policy-oriented studies in the sector (except for Ref. [20]). In our paper, we explore the question of science-policy interactions in the field of flood risk governance along three distinct analytical dimensions:

1. Dynamics of knowledge creation: The impact of climate change on flood risks became an important topic especially after the publication of the IPCC's Second Assessment Report [37]. Subsequently, in many European countries, one c seen extensive efforts of knowledge creation and the related 
consolidation of expertise on flood risks and related management options [3,38]. At the same time, the state of knowledge is—as almost necessarily seen in any complex policy arena-still highly provisional, uncertain and incomplete [13,39,40]. Against this background, our case studies address the following questions: How did the state of knowledge in the field develop over time, and was there consensus on key insights or did experts disagree? What kind of policy recommendations, if any, did scholars provide?

2. Institutionalization of the science-policy interface: The interaction between science and policy-making has often been conceptualized by means of a dichotomization between the two realms of knowledge production and knowledge use and, relatedly, the clear institutional separation of the two. Recently, this "two-communities" model has given place to a more differentiated picture: Science-policy studies indicate that sectoral arenas are frequently marked by a great variety of "knowledge actors" - beyond the simple binary classification between "scientist" and "policy-maker"; often with one and the same actors taking different roles depending on the context. This is also reflected in different models of organizational integration, where especially in neo-corporatist policy cultures, like the Netherlands or the German-speaking countries, one often finds "mixed" advisory bodies in which policy-makers, administrative officials, interest group representatives, and scientists sit side-by-side without a clear separation of roles [41,42]. Before this background, we ask the following questions: Who are the main "knowledge actors" in the policy domain of flood risk governance? How is the interface between science and policy-making organized?

3. Influence of expertise on policy development: Flood risk management is seen as a highly technical field in which scientific expertise is expected to play an important role. As shown above, part of the management-oriented literature has been calling for a (more) evidence-based approach to address flood risks often building on an overly simplified linear "get-the-facts-then-act" model [43] (p. 406). In the light of recent scholarship, the naïve hopes of the cascade-like "scientification of the non-scientific world" [44] (p. 382) turned out to be untenable, both from a theoretical and an empirical perspective [26,45]. The critique goes in two directions: First, scholars point out that research findings are rarely directly employed in a specific policy, however, they can still exert a powerful influence over the terms used and the way issues are framed and understood (i.e., "conceptual use", [46]). Second, authors highlight that political actors can use scientists, their expertise, but also their nimbus of objectivity, as an additional resource to increase their authority or legitimation. Advisors are selected not only for their knowledge but also for the legitimation that they provide for policies as well as for policy makers and interest groups involved in policy processes [41] (p. 31). Before this background, we ask the following questions: How evidence-based are flood risk policies? How much influence and authority did science hold and how much is accrued to other modes of knowing and deciding?

We explore these research questions in a comparative case study for three neighboring countries/states in the wider Alpine region: Austria, Southern Germany (namely, the states/Länder of Baden-Württemberg and Bavaria) and Switzerland (see Figure 1). We selected these three cases for our comparison because they are all located within the wider Alpine region and thus share similar challenges with regard to flooding. For one, due to the mountainous topography, these regions are particularly exposed to a high frequency of heavy precipitation events, while the concentration of vulnerable land uses in valley basins results in high economic losses in the event of flooding [13,47]. Secondly, Austria, Germany and Switzerland are federal countries, where flood policies are marked by a complex distribution of responsibilities between the national, state and municipal levels, with the state level (i.e., Länder/cantons) assuming strong operational responsibilities in flood risk management and climate change adaptation. This also explains why we decided to analyze two Länder (Baden-Württemberg and Bayern) rather than the entire country for the case of Germany. 


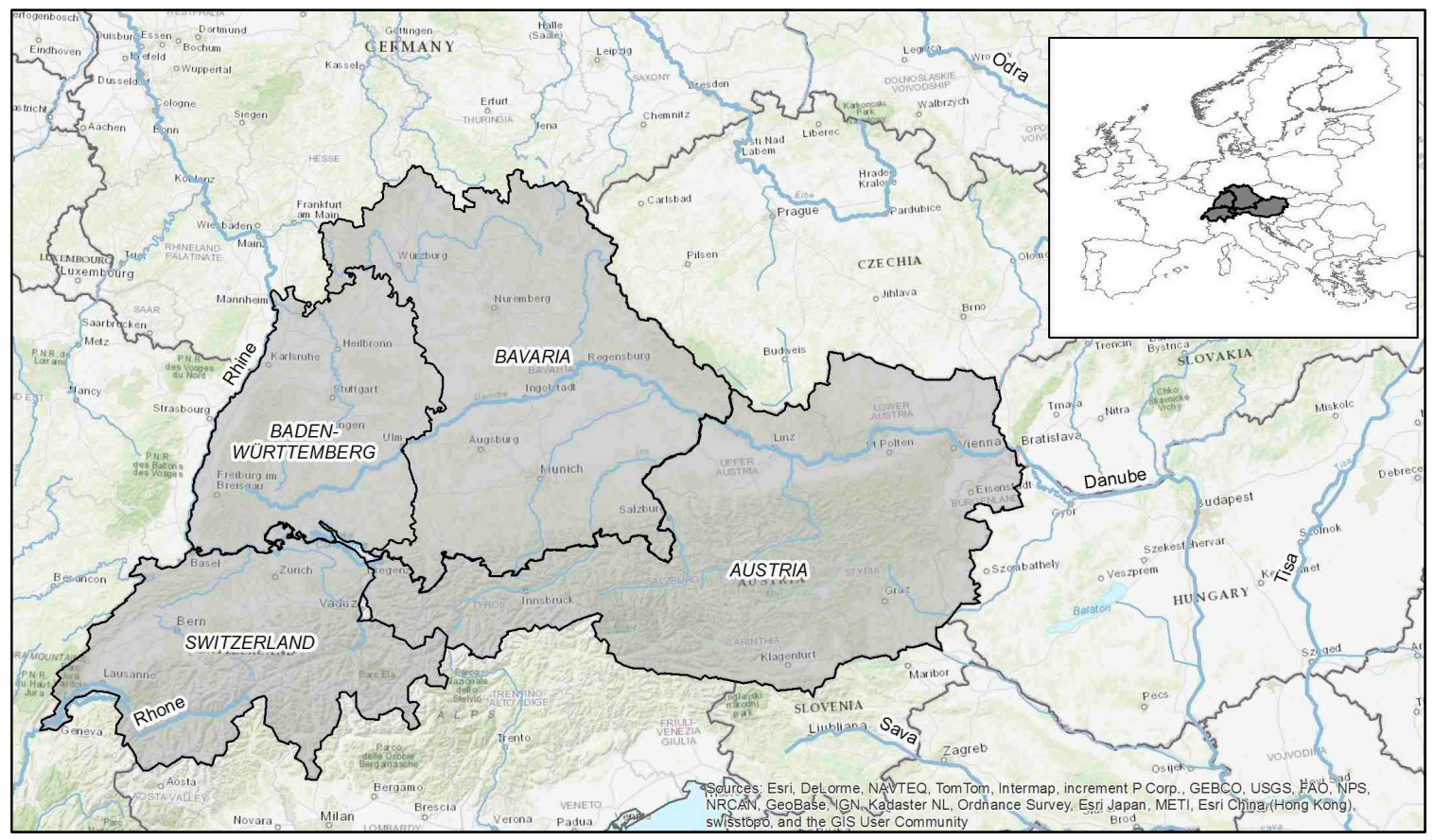

Figure 1. Overview of the case study regions Austria, Switzerland and Southern Germany (Bavaria and Baden-Württemberg).

Despite their parallels, the three regions, however, exhibit considerable differences in the way they deal with the possible climate-related influences on flooding. Methodologically, the paper is based on a qualitative analysis [48,49] of scientific and grey literature as well as relevant policies, strategies, and project documents. Complementary to the document analysis, we conducted a total of 24 semi-structured interviews with scientists, water policy experts, engineers, and policy-makers of the three regions (between June 2016 and June 2018) (for a list of interviews see Table A1 in the Appendix A). The collected data set has been anonymized, coded and interpreted using the qualitative data application MAXQDA 12.

\section{The Role of Climate Change in Flood Risk Management in Austria, Southern Germany and Switzerland}

This section explores science-policy interactions in the field of flood risk governance for the case study regions in Austria, Southern Germany and Switzerland. We structure the empirical analysis along the three dimensions outlined above, namely (i) dynamics of knowledge creation; (ii) institutionalization of the science-policy interface; and (iii) pathways of influence of expertise on policy development.

\subsection{Austria: Flood Risk Adaption without Climate Change Allowances}

Austria experienced a series of major flood events in 2002, 2005 and 2013. Those events caused flood risk management in Austria to shift to new priorities. A broad discussion about future flood risks and the impact of climate change thereon has emerged since 2002. Until today, Austria has not introduced specific adaptation instruments such as climate change allowances, but future uncertainties are incorporated into the planning practice by various alternative means.

\subsubsection{Dynamics of Knowledge Creation}

The first studies on the possible effects of climate change for individual regions in Austria were published in the early 2000s [50-52]. Due to the different characteristics of the investigated catchment areas, but also because of the different methodological procedures and different input 
data, the results of these studies in individual catchment areas are not directly comparable. However, the main results of these studies were quite similar. Godina [52] showed-based on 120 annual series of observations-different trends for three rivers in Austria: rising trend on the Salzach, falling trend on the Enns and a slightly falling trend on the Inn. Nachtnebel and Fuchs [51] found no indication for a climate signal leading to higher flood hazards based on their scenario analyses. Blöschl and Merz [53] analyzed different flood events (period 1828-2005) on the Danube near Vienna. The overall time period showed an increase in small floods, but no trend in large floods and an increase in winter floods at the expense of summer floods. From all these studies, no climate-induced changes in the discharge peaks could be detected [54].

The extreme flood event of 2005 and two studies (commissioned by the World Wide Fund for Nature and the State of Upper Austria) by Refs. [54,55] renewed the discussion. In spite of being cautious in their conclusions, both studies argued that climate change would increase future flood risks: "In general, although it is not possible to quantify how ultimately the overall flood risk in Upper Austria will change as a result of climate change, changes must be expected in any case, in particular seasonal and regional shifts in risk" [56] (p. 21). This initiated a new wave of studies in the following years that took a closer look at the effects of climate change on flood hazards [57-60].

In the early 2010s, the Austrian Ministry of Agriculture, Forestry, Environment and Water Management (BMLFUW) and the Water Resources Divisions of the State Governments commissioned a comprehensive sectoral study on water management as part of the Austrian Climate Adaptation Strategy [61]. The aim of the study was to assess climate impacts on water resources based on the most recent data and methods, and to derive policy recommendations on climate change adaptation strategies for water resources management in Austria [62]. The study shows that during the period 1976-2007, increasing trends occurred in about $20 \%$ of the catchments, particularly north of the main Alpine ridge. However, if one extends the analysis period to 1955-2007, the trends are much less clear because a number of major floods happened in the period 1955-1975. It also shows that winter floods have increased significantly more than summer floods. The authors conclude that the accumulation of flooding in recent decades lies within the natural variability of flood decades, but that an influence of climate change cannot be ruled out. Furthermore, they conclude that the introduction of a general climate allowance for design values is not required at the current state [61,62].

The findings of the so-called "Blöschl study" [61] settled the scientific discussion for the following years. The study was updated in 2018 [54]. The new findings confirmed many of the previous results, but showed a somewhat stronger influence of climate change. In the future (time horizon 2021-2050), regionally different changes in flood discharge are expected to be in the range of -4 to $+10 \%$ (for one-year flood events). The updated study reiterates the conclusion that a climate change allowance is currently not required in Austria, but it points to a higher number of catchment areas with rising trends and highlights the increasing risk from pluvial floods.

\subsubsection{Institutionalization of the Science-Policy Interface}

Scientific expertise is very important for decision-makers in Austrian flood policy. As two of our interview partners stated: "Science is certainly the basis for the flood risk management that we have developed in recent years" (Interview AT02), and there is "a great deal of openness towards scientific findings" (Interview AT03 (all direct quotes from interviews are translated from German)).

After the extreme flood event of 2002, a research program called FloodRisk was initiated. FloodRisk brought together scientists and public officials from a variety of fields such as meteorology, hydrology, geomorphology, natural hazards, damage assessment, law, spatial planning, and disaster protection. It followed a broad approach, which one of our interview partners describes as follows: "As a result of the 2002 events, actors suddenly realized that this has much, much wider dimensions and much of what went wrong in Austria, in my view, has to do with the fact that key players (...) have not used science to reflect on how to improve flood risk management" (Interview AT04). Despite its broad approach, the FloodRisk program did not focus on climate change in particular. Shortly after the final 
report of FloodRisk was published, in 2005, another extreme flood event hit Austria and a follow-up program (FloodRisk II) was established, this time including a sub-project on the impact of climate change on floods [57].

While FloodRisk stands for a disaster-driven type of science-policy interaction, there are also more structural, long-term venues in which decision-makers, professionals and scientists interact. An important network is the Austrian Water and Waste Management Association (ÖWAV) (Interviews AT02; AT05). The ÖWAV acts as an information and communication hub that provides early information on legal, technical and economic developments and supports the exchange of experience in the field of water management. It has established a working group on flood protection in particular to engage with municipalities and flood water associations. The aim of the working group is to provide a platform for decision-makers, municipalities, authorities, planners, universities and industry in flood risk management and to develop, coordinate and bundle activities for this target group. The ÖWAV has organized seminars in 2009, 2016 and 2018 to discuss the impact of climate change on water management in Austria [63]. In 2014, it published an expert paper to assess the impact of climate change on water management based on the ZAMG/TU Wien study and to discuss the need for further adaptation measures [64].

\subsubsection{Influence of Expertise on Policy Development}

The close relationship between scientists and public officials, and the regular exchange among members of the flood community led to an evidence-based flood policy in Austria. The findings of the major studies on the impact of climate change are mentioned in every relevant policy document, often cited literally. The first document of the federal ministry that referred to climate change as a possible driver of flood hazard was published in 2006, and it was clearly influenced by the earlier studies of Refs. [49-51]. In this document, the federal ministry asserts that "whether the hydrologic extremes of 2002 and 2005 and the increasing frequency of local heavy precipitation in the last years are signs of a global climate change cannot yet be clearly determined. Developments are to be followed closely and-if necessary-need to be taken into consideration for flood protection" [65] (p. 7). After the "Blöschl study" was published in 2011, it became the new point of reference. The Austrian Climate Change Adaptation Strategy from 2012 states: "Due to the prognostic uncertainties about the actual effects of climate change on the different regions in Austria, a general increase in these design values by a factor $X$ is currently discouraged by the scientific community" [66] (p. 172). The report of the Austrian Panel on Climate Change [67], the expert paper of the ÖWAV [64], and the National Flood Risk Management Plan [68] all refer to the Blöschl study and basically copy-and-paste the findings as well as the policy recommendations. The update of the Blöschl study in 2018 will probably become the new reference point. The latest publication by the federal ministry has already taken into account some of the findings: "The hydrological extremes of local intensive rainfall events currently still match the historical variation. However, it becomes ever more likely that they are a consequence of global climate change" [69] (p. 11).

Adaptation to likely future flood risks is a multi-causal process in Austria in which uncertain climatic factors are overshadowed by highly likely socioeconomic trends such as land-use change induced by population and economic growth [70,71]. For various reasons, Austrian flood policy makers are not willing to account for possible climate-induced changes in flooding, e.g., in form of a precautionary climate allowance to runoff calculations (as in parts of Germany, see Section 3.2). First, they point to the lack of scientific evidence suggesting that flooding will increase in Austria due to climate change (see Section 3.1.1). Second, since implementing a precautionary climate allowance would increase the costs of structural flood protection drastically (Interviews AT02; AT05; AT07), this would reduce the number of projects that can be implemented with the same budget (Interviews AT05; AT06). Third, some experts see such a precautionary orientation in structural flood defence to be in conflict with the federal prioritisation of non-structural measures, and they assume that a "levee effect" could increase the damage potential in protected areas (Interviews AT02; AT08). 
Despite the fact that Austria has not added a climate change allowance to its design values, it would be short-sighted to conclude that until now Austria has not actively factored-in the effects of future climate change into its flood risk management strategies. Policy-makers and scientific experts stress that in many areas, potential climate change influences are already incorporated into planning practice, as extreme events lead to an adaptation of the design values for flood protection measures (Interviews AT02; AT07). The federal government also improved design standards such as the safety allowance (called "freeboard" in Austria), which is added to the calculated design of flood defence infrastructure as a "buffer" to accommodate for epistemic and modelling uncertainties. On the state level, water management authorities started to take the issue of local intensive rainfall more seriously. Facing an increase in heavy rainfall, as a likely result of climate change, for instance the Governments of Lower Austria and Styria have recently developed a state-wide hazard map for surface runoff, which could provide a comprehensive hazard information base for flood proofing measures in areas prone to pluvial floods.

\subsection{Southern Germany: Early Awareness and Institutionalization of Climate Change Impacts}

The Southern German states of Baden-Württemberg (BW) and Bavaria (BY) witnessed several major flood events with devastating losses: Rhine floods in 1993 and 1995; Alpine floods in 2000 and 2005; and Danube floods in 1999, 2002, and 2013. Scientists and professionals engaged in looking at possible connections between climate change and regional extreme flood events already early on, i.e., in the 1990s. Consequently, BW and BY became the first federal states in Germany to introduce a technical flood risk instrument explicitly focused on addressing the impact of climate change, namely the Climate Change Factor.

\subsubsection{Dynamics of Knowledge Creation}

During the early 1990s, the hydrologists Bárdossy and Caspary published the first studies on the connections between climate change, European atmospheric circulation patterns, and extreme flood events for Southern Germany [72,73]. Their statistical analyses indicated for some catchments in BW a connection between increased temperatures and changes in the stationarity and frequency of flood events [73]. At first, those studies triggered negative reactions from policy-makers and some scientists of the Southern German water management community, who criticized the methodological approach and, consequently, cast doubt on the relevance of human-induced climate change for floods (Interviews DE01, DE02, DE05). Professionals argued that the sector always had to deal with climatic variability and natural climatic cycles and their related impacts on flood-proneness (Interview DE03). Additionally, flood risks were seen to be contingent on land use changes and other societal dynamics. Therefore, some experts argued that the sector was not dealing with a "fundamentally new situation" [74]. This early criticism and rebuff later turned into generally high interest, political and technical, to systematically examine the causality between climate change and flood risks, and to develop their own regional climate and hydrological models (Interviews DE01, DE02).

The ensuing studies produced during the late 1990s and early 2000s showed high degrees of variance and uncertainty with regards to a possible link between climate change and extreme flood events in Southern Germany. Study results varied among different catchments (especially depending on whether catchments are influenced mainly by precipitation or also by snowmelt), but they also varied along the technical parameters used in the different case studies, including the length of historical data series, or the chosen modelling methods and ensembles [75-77]. Long-term analyses of hydrological parameters showed for the period 1932-1998 no significant, area-wide trends of flood discharge increase. Only when reducing the period under consideration to the last 30 to 40 years of recorded data, most of the analyzed gauging stations showed increases, especially during the winter half year [74]. Regarding future scenarios, early KLIWA-studies presented estimates of an increase of mean annual floods and their frequency, again especially during the winter half year [74,78-80]. At the same time, studies on extreme and rare flood events under climate change influence showed a relatively 
low increase [79]. Overall, scientists largely agreed on their assessment that human-induced climate change would not have sweeping effects on flooding patterns in Southern Germany, however, it might lead to a locally differentiated increase in floods [77].

In the late 2000s and 2010s, KLIWA continued its monitoring program based on historical data while developing more complex climate and impact models and partly extending its research focus by paying larger attention to heavy precipitation [81-83]. Overall, the key messages resulting from those studies have not changed much, but one still sees some minor shifts: Studies of long term flood discharge behavior (1932-2015) now show positive trends for the majority of gauging stations as well as an increase in the significance of those trends, both for the whole year as well as for the winter half year [84-87]. Concerning future scenarios (2021-2050, 2071-2100), simulations of the mean monthly flood discharge for the winter half year indicate for BW an increase of flood discharge trends for the nival flow regime and a strong increase for the pluvial flow regime [86]. For BY, flood discharge projections show mixed results with strong spatial variations $[82,86]$. These findings are also supported by Hatterrmann et al. [88], who showed that a considerable increase in flood-related losses can be expected in Germany in a future, warmer climate.

Given the unclear trends and the high degrees of uncertainty inherent in early studies, it is interesting-if not to say surprising - to see that KLIWA scientists in 2004 explicitly suggested implementing a Climate Change Factor (CCF). They presented the CCF as a flexible non-regret adaptation instrument to be included in the planning of all new technical flood protection measures. As will be described in more detail in Section 3.2.3, the CCF was readily taken up by policy-makers both in BW and BY. In recent years, KLIWA has become more cautious with specific policy recommendations: Emphasizing the inherent uncertainties that come with future projections, scientists tend to suggest rather "soft" instruments such as guidelines for municipal management of heavy rainfall risk [83,89].

\subsubsection{Institutionalization of the Science-Policy Interface}

In both fields of climate change policy and flood policy, South-German decision-makers have for a long time strongly relied on the technical expertise of their respective environmental agencies, that are the Baden-Württemberg State Institute for the Environment, Survey and Nature Conservation (LUBW) and the Bavarian State Office for the Environment (LfU) (Interview DE06). In our interviews, those agencies were described as the first-hand technical and scientific advisory bodies that connect, translate, and moderate between science and policy (Interviews DE01, DE04, DE07, DE09). Also, in institutional terms, both agencies occupy a hybrid space as they collaborate with scientists, private engineering firms, communities, and federal state policy-makers. They draw on external technical expertise in various ways, mostly under the formats of commissioned research and short-term project work, either through public tendering or by approaching research groups or scientists directly (Interview DE04). The water management sector is described as a closed community with strong ties between science, engineering and policy-making (Interview DE10).

A new space for science-policy interactions was introduced with the Cooperation Project Climate Change and Consequences for Water Management (KLIWA) in 1999. The formation of KLIWA was, among other reasons, a reaction to the scientific debate of the early 1990s publications mentioned above and the first and second IPCC reports (Interview DE01). KLIWA has been led by the respective environmental agencies of BW and BY in cooperation with the German Meteorological Service (DWD). With its explicit focus on climate change, KLIWA has been seen as a pioneer initiative in the water sector, not only for Southern Germany but also at the federal level (Interview DE01, DE02, DE03). Its purpose is to scientifically and technically examine the connection between climate change, extreme floods and other impacts on the water sector as well as to provide science-based recommendations for decision-makers (Interviews DE01, DE04, DE07) [90].

KLIWA has been organized along the areas of long-term observations of meteorological and hydrological data; modelling future developments; monitoring and assessing current impacts; adaptation strategies; and public outreach $[90,91]$. Central to the ongoing work of KLIWA has 
been its communication to the expert community and decision-makers through different formats e.g., symposiums and experts' conferences, monitoring reports, project publications, and short informative posters.

\subsubsection{Influence of Expertise on Policy Development}

The tight institutional coupling of science and policy-making, as most prominently enshrined in KLIWA, is also reflected on the policy level. In our interviews, both policy-makers and scientists approved and valued their close cooperation and they emphasized the benefits of evidence-based policy-making (Interviews DE03, DE08, DE10). The most direct impact of expertise on policy-making goes back to the early 2000s. In 2004/2005, both BW and BY introduced the Climate Change Factor $(\mathrm{CCF})$ as a first concrete policy instrument to address possible future climate change risks. KLIWA played a crucial role in that: In KLIWA reports, the CCF was presented as a flexible, non-regret adaptation instrument to be used in design floods and the planning of new technical flood protection measures [74,92]. BW introduced the CCF based on rigorous scientific analyses of regional data by LUBW and the Karlsruhe Institute of Technology. LUBW, in cooperation with engineering partner companies, developed the "Guideline for Determining Design Floods for Technical Flood Protection". Those guidelines recommend the use of a set of regionalized factors (ranging from $0 \%$ to $+75 \%$ ) in design floods and corresponding technical flood protection measures. In BY, a CCF was introduced at the same time as in BW, even though regionalized results were not yet available for all BY catchments. In BY, decision-makers chose to adopt a general factor of $+15 \%$ for all catchments. The political decision to adopt the CCF was announced at the KLIWA Symposium 2004 in Würzburg. With the adoption of the CCF, policy-makers claimed to follow the precautionary idea of taking action in spite of uncertainties, but allowing for future corrections of data and modelling ("no regret strategy") (Interviews DE01, DE04, DE07, DE05, DE02, DE03).

The CCF in BW and BY was an early instrument that was developed and adopted before Germany reformed its Water Act (2009), implemented the EU Flood Risks Directive (2007), and developed its Climate Change Adaptation Strategy Program (2008). The CCF was introduced as a non-binding recommendation to be adopted only under cost-benefit considerations in BW [93], and as an obligatory measure in BY, where exceptions can be considered in individual cases [94]. In practice, it is applied only on new linear technical flood protection measures of narrow scope, and not on larger technical measures such as dams, polders, and wide retention measures. The CCF can be seen as a rather stand-alone instrument, which is still technically implemented, but it has not been explicitly revised or updated, and its effectiveness, applied scope or impact have not been assessed (Interviews DE04, DE07).

Since the implementation of the CCF, the flood risk management sector in BW and BY has introduced several other measures, all of them driven by the precautionary principle. Yet, the sector is still oriented towards a more technical approach of flood protection. This can be seen by a recent initiative in BY: Based on studies of estimation, flood waves and in-depth impact analyses of the Bavarian Danube conducted by the Technical University of Munich [95,96], the State Government adopted the "Bavarian Polder Program". This program accounts for 12 potential sites for the construction of controlled polders along the Danube. The Polder Program has been presented as a means to increase the resilience of flood protection infrastructure by expanding retention volume and to reduce flood risk for downstream cities in the case of overload [96,97].

\subsection{Switzerland: Integrating Climate Change Adaptation into Flood Risk Management}

Following a "disaster gap" between the late 1880s and the late 1970s [98], Switzerland experienced an active period of flooding in the past three decades, including two particularly damaging events in 1987 and 2005 [99]. Swiss flood policies responded to the deficiencies of technical flood defenses by adopting a more integrated approach to flood management. Flood policy-makers at an early stage acknowledged the likely adverse consequences of climate change and integrated climate adaptation strategies into flood risk management. 


\subsubsection{Dynamics of Knowledge Creation}

In the late 1980s, a long-term study of flood discharge changes in Swiss rivers found no significant trends in the majority of catchments [100]. A sequence of damaging events in the 1990s $(1992,1993$, 1994, 1999), however, prompted scientists to take a closer look at the observed changes in flood frequency. In one of the first encompassing studies, Frei et al. [101] explored the linkages between climate change and flooding for Switzerland. The study (i) suggests an interrelationship between changes in atmospheric circulation and the frequency of extreme events, and (ii) indicates that climate change will result in a "growing proportion of rainfall ( . . . ) which will accelerate the runoff formation process" (p. 296). In a study on "Extreme Events and Climate Change" [102], scientists underline the difficulties to "identify or exclude a statistically valid trend in the frequency of rare extreme events". A follow-up study, however, confirms that, "as a result of the expected changes in the precipitation regime, more frequent and in part larger floods are expected (...), in particular in winter and the transitional seasons" [103] (p. 60).

In response to the 2005 flood events, Switzerland's Federal Office for the Environment (BAFU) commissioned two studies to explore the long-term changes in observed flood frequencies in Switzerland since 1850 and 1500, respectively [104,105]. The studies show that periods with frequent flooding historically alternated with quieter periods. While the analysis since 1850 indicates a large number of measuring stations with upward trends, from a long-term perspective (i.e., since 1500) it becomes evident that the recent flood-rich period (starting in the late 1970s) "is still in the range of formerly observed ones (...) and might continue for some decades under natural climate variation" [105] (pp. 1591-1592). However, the recent accumulation of large flood events in northern Switzerland "suggests that the (observed) changes in flood frequency in Switzerland are due to changes in atmospheric circulation" [104] (p. 6).

Climate projections are detecting increasingly clear signals that both seasonality and magnitude of floods in Switzerland will change in the future. With rising temperatures, more heavy rainfall events and a pronounced shift from solid (snow) to liquid (rain) precipitation is expected, which could increase the frequency of occurrence of extreme events, especially during the winter season [106-109]. These findings are supported by a more recent report by the Swiss Academy of Sciences, which points to the difficulties of projecting future change in extreme flood events but highlights that climate effects on the hydrological cycle lead to an increase in flood volumes and that an increase in flood risk is expected [110].

The latest Climate Change Scenarios for Switzerland (CH2018) substantiate the above projections with more robust climate evidence. They highlight that "heavy rainfall is projected to intensify in all seasons (...) for all event categories". Across Switzerland, flood events relevant for infrastructure planning (i.e., 10-year floods and 100-year floods) "may intensify strongly in all seasons". Compared to earlier reports "confidence in heavy rainfall intensification is now substantially higher", inter alia due to improvements in the resolution and accuracy of the new generation of climate models [111] (p. 10).

Regarding their advice for flood policy, climate scientists in Switzerland are rather cautious. For instance, Schmocker-Fackel and Naef [104] recommend that "future flood protection measures should (...) take into consideration the observed cyclical behavior of flood frequency" (p. 7), while Frei et al. [101] highlight the importance "to invest in reducing the negative impacts of extreme events, irrespective (and not knowing) whether these are of anthropogenic or natural origin" (p. 297).

\subsubsection{Institutionalization of the Science-Policy Interface}

Switzerland's flood risk management builds on strong institutional ties with research institutions and scientists. This goes back to the origins of modern flood defense, when scientific experts were commissioned by governmental authorities to investigate the root-cause of the seminal flood events in 1868. Their expertise and recommendations provided the basis for the legislative organization of responsibilities in Switzerland's natural hazard management [112]. More than 100 years later, following the disastrous floods in 1987 and 2005, scientific expertise yet again provided impetus for 
policy change. Together with policy officials and practitioners, scientists played a leading role in the post-event documentation and analysis [113], and thus, provided the necessary evidence base for the subsequent changes in flood policies (see Section 3.3.3).

Organizational integration of knowledge actors plays an important role in the institutionalization of science-policy interactions in Switzerland. This becomes evident by the example of BAFU, which is responsible for setting strategic priorities and for co-funding disaster risk reduction measures, and guides the federal governments' efforts to assess the impacts of climate change on natural hazards [114]. BAFU bundles expertise related to flood risk management in different organizational divisions and traditionally has strong personal and institutional ties to the leading research institutions in the field, which serve not only as partners in climate-related contract research but also as a recruitment pool for administrative officials (Interview $\mathrm{CH} 02$ ). Given its role as a pivotal administrative authority on the federal level, BAFU thus assumes an intermediary role between science and politics in flood risk management: whereas the latter provides the financial and legal frameworks for flood risk management, science delivers the knowledge base to further develop and implement flood risk management in practice (Interview $\mathrm{CH} 01$ ).

To facilitate climate-related research and to strengthen linkages between scientists and policy-makers, in 1988 the Swiss Academies of Sciences launched the ProClim initiative as part of the wider Platform Science and Policy. As an "interface for communication between science, public administration, politics, economy and the public", the platform plays a strong role in preparing the existing knowledge in climate research to support decision-making (Interview CH01). A more specific platform for the exchange of knowledge actors in natural hazard and flood risk management is the so-called FAN Association (Fachleute Naturgefahren Schweiz), which includes more than 460 members with different institutional and disciplinary backgrounds. The majority of members are private actors $(44 \%)$, such as engineering consultants, but with a large share of actors from the administrative sector $(21 \%)$ and academia (18\%), the association assumes an important function to foster knowledge exchange between a range of actors in the field of gravitational hazards ([115]; Interview CH01).

Finally, the National Platform for Natural Hazards (PLANAT), established in 1997 by the Swiss Federal Council, provides an overarching framework for the interaction between science, public administrations and private actors. PLANAT has the mandate to set strategic priorities for an inter-sectoral, whole-of-society approach in risk management and to coordinate activities and foster knowledge exchange $[114,116]$. In that capacity, PLANAT also acts as an editor of guiding documents, including the national strategies for the integrated management of natural risk $[117,118]$ but also for specialized policy reports e.g., concerning risk-based spatial planning [119].

\subsubsection{Influence of Expertise on Policy Development}

Already at an early stage, Switzerland adopted a proactive stance regarding the possible climate-related effects on flooding. In the late 1990s, the founding document of PLANAT highlighted that "climate change and the tendency towards extreme weather events may further increase related risks" ([115]; translation from German). A few years later, a guiding policy document in hydraulic engineering suggested that "the risk of [flood] hazards could generally intensify in coming decades due to external influences (e.g., global climate change)" [120] (p. 7).

The above policy documents were issued before publication of the respective scientific studies (cf. Section 3.3.1), indicating that they were informed by the mounting awareness for climate change in the late 20th century, inter alia following the Second IPCC Assessment Report in 1996 [121]. In particular, following the succession of large flood events in the late 1990s and early 2000s, policy makers were eager to learn more about the climate-related effects on flooding (Interview $\mathrm{CH}$ 03). In response to the 2005 floods, BAFU commissioned two scientific studies to build a stronger evidence base concerning the long-term changes in flooding and the possible climate influences [104,105]. Later policy documents explicitly refer to the scientific literature, although the statements concerning the climate effects on flooding are not necessarily more concrete [122-124]. 
Despite - or rather, given - the lack of hard evidence of climate change effects on flooding, scientific studies nevertheless supported the shift from hazard defense towards an integrated approach in flood risk management $[125,126]$. Following the 1987/2005 flood events, Switzerland's flood policies were oriented towards reducing flood discharge and increasing the "robustness" of technical defenses against flood overload $[127,128]$. The integrated approach in Swiss flood policy aims at planning for extreme events irrespective of the actual influence of climate on flood discharge. According to a leading policy-maker, the nascent paradigm may thus be described as "congruent" with Switzerland's precautionary stance in climate change adaptation (Interview CH01).

The synergies between this reorientation in flood policies and climate change adaptation are specifically reflected in the trans-sectoral pilot program "Adaptation to Climate Change", which was launched under the auspices of BAFU to support cantonal and municipal efforts in meeting climate adaptation challenges [129]. Within the framework of the program, a total of 31 projects were implemented between 2014 and 2016, thereof two directly related to the nascent flood policies. The pilot projects had an experimental format where scientific expertise played a lesser role. Although research institutions were eligible for funding, the selected projects mainly involved public authorities (cantons, municipalities) as well as professionals/practitioners (e.g., consultants, engineering bureaus) to support the practical implementation of the respective climate adaptation measures [129].

In sum, Switzerland strongly aligns climate change adaptation and flood risk management [122]. Flood policy's active stance in implementing Switzerland's Climate Change Adaptation Strategy as well as the involvement of administrative authorities in the assessment and monitoring of climate change demonstrates that policy actors in this field "consider adaptation increasingly on equal terms with other sectoral policy objectives" [130]. Climate science plays an important part in the reorientation of flood policy by providing the much-needed evidence to assess the climate effects on flooding. To support the implementation of future-oriented risk management strategies, flood policy, however, also relies on expertise from other disciplines (e.g., spatial planning), while non-scientific knowledge actors, in particular technical experts and municipalities, are important partners for implementing in practice the nascent paradigm of integrated flood risk management.

\section{Cross-Case Comparison and Discussion}

This paper analyzed the science-policy interactions in the field of flood risk governance against the background of climate change for the case studies of Austria, Southern Germany and Switzerland. We structured the empirical analysis along three dimensions: (i) dynamics of knowledge creation; (ii) institutionalization of the science-policy interface; and (iii) pathways of influence of expertise on policy development. Based on the current literature, we started with the assumption that climate change would not (yet) be widely and explicitly reflected in flood risk governance [9]. However, our case studies show that there is a mixed, though increasing impact of climate change on flood risk governance in the three selected Alpine regions. Climate adaptation has become an important issue of flood policy in all three case study regions and this shift has been strongly supported by evidence-based arguments (see Table 1 for a comparative overview of the case study findings).

Concerning our first analytical dimension, i.e., the dynamics of knowledge creation, our case studies indicate that there has not yet been scientific closure on the impact of climate change on flood hazards. In the 1990s and early 2000s, studies were often afflicted by methodological problems and data gaps. This created dissent in the Austrian and German scientific communities, when the findings of some studies were criticized. In the last 10 years, many of these problems were solved due to more comprehensive historical data and better climate and hydrological models. Nowadays, there is a broad consensus among scientists in all three regions about the potential impact of climate change. Nevertheless, epistemological and methodological uncertainties remain, in particular with regard to major flood events, which are difficult to predict in the Alpine region. This can, inter alia, be seen when comparing insights derived from historical trend analyses with those of modelling approaches: For Austria and Germany, those insights converge, however, content-wise they point to opposite 
directions (with Austrian studies seeing few and German studies seeing numerous indications of climate change signals). In contrast to that, for Switzerland, historical trend analyses show a weak signal, whereas models indicate a strong(er) influence, particular concerning heavy rainfall events. This strong variation on the regional and sub-regional level in both the observed and expected changes in flooding is somewhat surprising, but can be explained by the topographic effects of the Alps and the countries' different susceptibility to cyclone tracks (cf. Ref. [100]).

The case studies further indicate that scientists adjusted their expertise to political expectations: When climate change emerged prominently on the political agenda, the production of application-oriented expertise followed suit. This can be interpreted as an effort of experts to ensure that they remain a valid source of knowledge for decision-makers. Strassheim and Kettunen [131] and Van Enst et al. [132] denote this phenomenon with the concept of "policy-based evidence"-as compared to the classical notion of "evidence-based policy" with a more linear understanding of science-policy interactions.

However, the case studies still show some variance in the degree to which experts lend themselves as advisors for policy: In Austria and Germany, experts provided quite explicit recommendations, with German scholars recommending the introduction of an explicit climate change instrument, i.e., the Climate Change Factor, and Austrian scholars explicitly recommending not to implement such an instrument. In Switzerland, scientists provided more cautious and partly ambiguous recommendations, thereby leaving the final decisions to policy-makers. These divergent patterns between countries are notable in various respects: On empirical grounds, it is interesting to see that even though the expert communities of the three regions regularly exchange views and experiences, we observe convergence neither on the level of recommended policy instruments nor on the level of advisory styles. With regards to the latter, the comparative science-policy literature would have made us expect that the three regions, because they share a similar neo-corporatist policy culture, would show similar patterns of interaction between science and policy-making [42,133-135]. Similarities can, for sure, be seen with regard to knowledge actors and organizational formats (see Table 1), however, not for the way scientists wriggle into politics.

With regard to the second analytical dimension, i.e., the institutionalization of the science-policy interface, we find that these are characterized in all three regions by a rather narrow set of actors consisting of scientists, public administrators, and political decision-makers. In the last decade, the scientific networks expanded and now include hydrology, meteorology, and spatial planning. Scientists play an important role in particular for risk assessments, while professionals and practitioners become more important when the discussion turns to risk management. In all three regions, we see a close cooperation between scientists and policy-makers, often including double roles and changes of roles. This is also reflected in hybrid platforms of knowledge exchange: In Austria and Switzerland, hybrid platforms mostly consist of scientists, administrative officials and political decision-makers, while in Germany those platforms are largely confined to scientists and administrative officials. The degree of institutionalization of those exchange platforms varies in the three regions, with the highest level of institutionalization in Switzerland, followed by Southern Germany, and the prevalence of more ad hoc, often event-driven, formats in Austria. Overall, there is a broad spectrum of science-policy interfaces: First, we have highly specialized organizations and research frameworks with a long continuity, such as ÖWAV in Austria, KLIWA in Germany, and PLANAT in Switzerland; second, we have specific research programs to generate focused research, such as FloodRisk in Austria and the pilot program on climate adaption in Switzerland, which are more event-driven and temporary; and finally, we have short-term contract research for ministries that deliver studies on the impact of climate change, such as the Blöschl study in Austria. 
Table 1. Comparative overview of the case study findings.

\begin{tabular}{|c|c|c|c|c|}
\hline & & Austria & Southern Germany (BW, BY) & Switzerland \\
\hline \multirow[t]{2}{*}{$\begin{array}{c}\text { Dynamics of } \\
\text { knowledge creation }\end{array}$} & $\begin{array}{l}\text { Development of } \\
\text { state of knowledge } \\
\text { over time }\end{array}$ & $\begin{array}{l}\text { Early/mid-2000s: high epistemic uncertainties; studies } \\
\text { based on individual catchments; some disagreement } \\
\text { between meteorological and hydrology communities } \\
\text { Early 2010s: growing consensus about impact of climate } \\
\text { change on flood frequencies, seasonal shifts, } \\
\text { and pluvial floods } \\
\text { Future projections (time horizon 2021-2050): regionally } \\
\text { different changes in flood discharge ranging from }-4 \\
\text { to }+10 \%\end{array}$ & $\begin{array}{l}\text { Early 1990s: first studies trigger contentious } \\
\text { debate on link between climate change and } \\
\text { flooding patterns } \\
\text { Late 1990s: concerted efforts to systematically } \\
\text { study climate signals at regional level (as part } \\
\text { of KLIWA) } \\
\text { Early 2000s: historic studies show no clear } \\
\text { signals; future projections show some } \\
\text { increased trends especially for winter half year } \\
\text { 2010s: increased climate signals, but still high } \\
\text { degree of variability and uncertainty }\end{array}$ & $\begin{array}{l}\text { Since early 2000s: growing interest to } \\
\text { investigate climate-related changes } \\
\text { in flooding } \\
\text { Long-term studies provide } \\
\text { indications but no evidence of } \\
\text { climate-related influences on flood } \\
\text { frequencies/intensities } \\
\text { Since mid-2010s: increasingly clear } \\
\text { signals that climate-related changes } \\
\text { in the hydrological cycle will result in } \\
\text { more intense rainfall events } \\
\text { and flooding }\end{array}$ \\
\hline & $\begin{array}{l}\text { Expert-driven policy } \\
\text { recommendations }\end{array}$ & $\begin{array}{l}\text { Explicit recommendation: no need to introduce } \\
\text { a general climate surcharge for design values }\end{array}$ & $\begin{array}{l}\text { Early 2000s: explicit expert recommendation } \\
\text { to implement } \\
\text { Climate Change Factors (CCF) } \\
\text { 2010s: more cautious expert recommendations, } \\
\text { e.g., in the form of guidelines }\end{array}$ & $\begin{array}{l}\text { In general, rather cautious policy } \\
\text { recommendations, e.g., } \\
\ldots \text { policy makers should account for } \\
\text { cyclical variability of flooding } \\
\ldots \text { risk reduction efforts should be } \\
\text { pursued irrespective of clear climate } \\
\text { change signal }\end{array}$ \\
\hline \multirow[b]{2}{*}{$\begin{array}{l}\text { Institutionalization } \\
\text { of the science-policy } \\
\text { interface }\end{array}$} & $\begin{array}{l}\text { Main knowledge } \\
\text { actors }\end{array}$ & $\begin{array}{l}\text { Scientists (meteorology, hydrologists etc.) assess } \\
\text { historical trends and model future trends } \\
\text { Policy-makers and administrative officials build up } \\
\text { practical knowledge based on the assessment and } \\
\text { experience from past flood events }\end{array}$ & $\begin{array}{l}\text { Hydrologists, meteorologists, climatologists, } \\
\text { hydraulic engineers assess past trends and } \\
\text { model future trends } \\
\text { Experts from environmental agencies, and the } \\
\text { German Meteorological Service, policy makers }\end{array}$ & $\begin{array}{l}\text { Scientists (climatology, meteorology, } \\
\text { hydrologists etc.) assess past and } \\
\text { model future flood-related trends } \\
\text { Sectoral authorities (flood protection, } \\
\text { risk management, spatial planning) } \\
\text { are involved in the monitoring and } \\
\text { assessment of climate change }\end{array}$ \\
\hline & $\begin{array}{l}\text { Organization of } \\
\text { science-policy } \\
\text { interface }\end{array}$ & $\begin{array}{l}\text { Strong cooperation between policy-makers and science } \\
\text { since flood events of } 2002 \\
\text { Various organizations at the interface between science } \\
\text { and policy-making: } \\
\ldots \text { multi-year transdisciplinary research programs on } \\
\text { flood risk (FloodRisk) } \\
\ldots \text { well established platform for knowledge transfer } \\
\text { and exchange among politicians, administrative officials, } \\
\text { practitioners and scientists (ÖWAV) } \\
\ldots \text { regular reports on the impact of climate change on } \\
\text { the water sector since } 2011\end{array}$ & $\begin{array}{l}\text { Traditionally strong cooperation between } \\
\text { policy-makers and scientists } \\
\text { Flagship research cooperation project "Climate } \\
\text { Change and Consequences for Water } \\
\text { Management" (KLIWA) since } 1999 \\
\text { Ad hoc commissioning of research projects to } \\
\text { universities, engineering companies, etc. } \\
\text { Regular KLIWA monitoring reports, } \\
\text { and exchange/communication symposiums } \\
\text { and events }\end{array}$ & $\begin{array}{l}\text { Institutional ties between } \\
\text { administrative authorities and } \\
\text { scientific organisations } \\
\text { Various well-established } \\
\text { knowledge-sharing platforms for } \\
\text { science, policy and practice } \\
\text { PLANAT provides an overarching } \\
\text { framework to coordinate efforts in } \\
\text { climate-adapted risk management }\end{array}$ \\
\hline
\end{tabular}


Table 1. Cont.

\begin{tabular}{|c|c|c|c|c|}
\hline & & Austria & Southern Germany (BW, BY) & Switzerland \\
\hline \multirow{2}{*}{$\begin{array}{l}\text { Influence of } \\
\text { expertise on policy } \\
\text { development }\end{array}$} & $\begin{array}{l}\text { Evidence base } \\
\text { of policies }\end{array}$ & $\begin{array}{l}\text { Overall, flood policy is strongly evidence-based, } \\
\text { while still being driven by extreme flood events as well } \\
\text { Risk management is more influenced by state and local } \\
\text { policy-makers as well as professionals based on } \\
\text { pragmatism and knowledge about practical solutions }\end{array}$ & $\begin{array}{l}\text { Flood and climate change policies explicitly } \\
\text { refer to studies and evidence generated } \\
\text { through KLIWA }\end{array}$ & $\begin{array}{l}\text { Spatial planning and flood protection } \\
\text { experts develop climate adaptation } \\
\text { strategies based on scientific } \\
\text { assessments and past flooding } \\
\text { experiences } \\
\text { Policies are aligned with the priorities } \\
\text { defined in the climate change } \\
\text { adaptation strategy }\end{array}$ \\
\hline & $\begin{array}{l}\text { Strategic } \\
\text { considerations- } \\
\text { beyond science }\end{array}$ & $\begin{array}{l}\text { Scientific studies provide legitimacy for the flood risk } \\
\text { governance approach }\end{array}$ & $\begin{array}{l}\text { Reference to scientific studies serves } \\
\text { policy-makers to justify the precautionary } \\
\text { principle as overarching paradigm of the sector. } \\
\text { Formats like KLIWA help scientific expertise to } \\
\text { "seep into" policies }\end{array}$ & $\begin{array}{l}\text { Flood policy adopted a proactive } \\
\text { stance on climate change, before } \\
\text { climate scientists provided the } \\
\text { evidence-base for Switzerland } \\
\text { Experimental design of pilot actions } \\
\text { in climate change adaptation to } \\
\text { support climate-adapted } \\
\text { flood policies } \\
\text { Functional approach by integrating } \\
\text { climate change adaptation into flood } \\
\text { risk management }\end{array}$ \\
\hline
\end{tabular}


Concerning our third analytical dimension, i.e., the influence of expertise on policy development, our case studies show that experts had an important influence on flood policy-making in Austria, Southern Germany and Switzerland and that flood risk governance in these regions is to a great extent evidence-based. The close relationship between scientists and policy-makers described above creates policy frames that, by identifying the potential impact of climate change on flood hazards and specifying policy solutions for adaptation, constructed a coherent story around the "problem of future flood risks". Policy-makers in all three regions to a certain extent depend upon scientific expertise to act, which provides experts with an important source of influence in the policy-making process. At the same time, our case studies also reveal that policy-makers set limits on the influence of those experts: Scientists had to "tailor" their knowledge to the new political issue of climate adaptation to get their expertise recognized. This can most explicitly be seen using the example of the Climate Change Factor in Southern Germany, where a generally high political sensitivity for climate change questions led scientists to recommend the Factor in spite of a very uncertain scientific basis.

Against the above, we find that the influence of experts on flood risk governance can best be understood as being "socially embedded" [131] or "contextually embedded" [36]. The notion of "social embeddedness" [131] emphasizes that "expertise and evidence [need to be seen as] socially embedded in authority relations and cultural contexts" (p. 259). In the case of flood risk management, this embeddedness most prominently played out in the flood paradigms that the three regions embrace: Switzerland was an early mover towards integrated risk management ("risk-based spatial planning"), a shift primarily caused by the extreme flood event in 1987. Climate change became an issue in the early 1990s, but the explicit consideration of climate adaptation in the form of planning for flood overload was driven by the 2005 extreme event. Switzerland's risk-based approach to the management of natural hazard is also reflected in the recently updated PLANAT strategy [118]. Entitled "Management of Risks from Natural Hazards", the strategy not only differs semantically from the previous strategy "Protection against natural hazards" [136]. Against the likely climate-related increase in hazard potential and the accumulation in vulnerable assets, it importantly embraces the need to "adapt in a timely manner to changes in conditions" (p. 6), as a core principle of resilience-oriented flood risk management strategies [4]. In Germany, the flood community discovered climate change as a problem also in the early 1990s, which is embedded in a national debate in which climate change is of high importance. Based on the precautionary principle, Germany introduced an explicit instrument (CCF) for hazard mitigation already in 2004, yet the CCF was still embedded in the classical safety paradigm of technical flood protection. More integrated approaches were developed later on in Germany, and with that, the CCF took a back seat and became one among many other measures. In Austria, the new integrated paradigm of flood risk management was adopted somewhat later than in Germany and Switzerland, specifically after the extreme flood events in 2002 and 2005. The new flood paradigm has been consistently implemented since then through the avoidance of new risk and the reduction of existing risks. The discussion about the impact of climate change emerged also relatively late in 2006/2007 in Austria, and until today has yielded only a few specific climate change-related measures.

\section{Conclusions}

Our analysis of science-policy interactions in the flood risk management sectors of Austria, Southern Germany and Switzerland showed that there are clear imprints of climate change on the sectors' governance arrangements and dynamics, though we also observed marked differences between the three countries. Climate adaptation has become an important issue of flood policy in all three countries, and this policy shift has been strongly supported by evidence-based arguments. However, uncertainties, inter alia due to lack or incompleteness of trend data and/or discrepancies in flood hazard projections, still remain. This provides challenges for policy-making, both with regards to the question of how to technically deal with flood risk in the face of imminent but still unpredictable climate change impacts (an issue that our social-scientific paper cannot address) and with regards to the question of which role to assign to science and expertise and how to organize the science-policy interface 
in an effective way. On the last-mentioned question, our comparative analysis of science-policy interactions in three Alpine regions provides insights that might be of interest for decision-makers in other countries as well.

Our reconstruction of the temporal dynamics of knowledge creation showed that, over the last three decades, one sees an increasing scientific agreement about the possible impacts of climate change on the frequency and magnitude of floods. However, as our case studies demonstrated, the progression of knowledge in the field has been far from linear; we rather observed some marked shifts in the construction and interpretation of scientific knowledge, partly due to methodological innovations or the availability of new data sets, partly due to changes in the political environment (such as increased public sensitivities for climate change). Against the background of those observed discontinuities in knowledge dynamics, it seems to be wise for policy-makers to opt for adaptation strategies that are flexible and robust enough to account for changes in flood hazards in the future. Ideally, decision-makers should identify and implement "no-regret" or "low-regret" adaptation measures that are effective under different climate change scenarios and that can be modified in the face of new scientific evidence. Incorporating the potential effects of climate change into flood design guidelines by an adjustment for uncertainties or a climate change allowance like in Austria and Germany is one example for that kind of adaption. Shifting flood policies from structural flood defense to a broader portfolio of vulnerability-oriented flood risk management measures like in Austria and Switzerland is another complementary option for adaptation.

Our comparative analysis of the institutionalization of the science-policy interfaces revealed a broad spectrum of approaches with some conspicuous differences between the three case study regions (e.g., with Switzerland showing the most formally structured science-policy landscape and with Austria hinging more towards informal, ad-hoc setups). What all three regions have in common-and what we see as prerequisite for effective knowledge translation-is that there are firmly established institutions that enable an exchange between scientists and policy-makers. Otherwise, there might be a danger that in the disaster-driven sector of flood risk management, scientific arguments only get heard in the direct aftermath of severe flood events and get sidelined as soon as the public attention has shifted to another exigent topic.

Finally, our study on the influence of expertise on policy making confirmed that scientists and other experts had quite a strong role to play in the formulation of flood risk policies and the implementation of flood risk management strategies and measures. In the three case studies, we could identify a large number of partly divergent factors that might help to explain the influence of expertise, however, there are also some overarching insights that might be singled out as success factors. The flood risk governance arenas in Austria, Southern Germany, and Switzerland are marked by various venues in which scientists and policy-makers can interact on a regular basis. The most long-lasting-and probably also the most influential—venues are the ones with diverse membership, that is, venues in which scientists, administrators, planners, and ideally politicians come together on equal terms. Given the variety of challenges that flood risk governance is facing, it seems to be desirable to have a spectrum of some more 'political' science-policy arenas and some more 'scientific' arenas. Eventually, what has proven helpful is the publication of policy-targeted scientific reports on the impact of climate change on floods, like the sectoral adaptation studies in Austria, KLIWA studies in Southern Germany, and the Climate Change Scenarios for Switzerland.

Author Contributions: This research article was developed in a collaborative effort based on the following author contributions: conceptualization, R.N., L.L., M.P.J. and M.P.; methodology, R.N., L.L., M.P.J. and M.P.; validation, R.N., L.L., M.P.J. and M.P.; formal analysis, R.N., L.L., M.P.J. and M.P.; investigation, R.N., L.L. and M.P.J.; writing—original draft preparation, R.N., L.L., M.P.J. and M.P.; writing—review and editing, R.N., L.L., M.P.J. and M.P.

Funding: This research was funded by the AUSTRIAN CLIMATE AND ENERGY FUND, grant number KR14AC7K11809.

Acknowledgments: The open access publishing was supported by BOKU Vienna Open Access Publishing Fund. 
Conflicts of Interest: The authors declare no conflict of interest. The funders had no role in the design of the study; in the collection, analyses, or interpretation of data; in the writing of the manuscript, or in the decision to publish the results.

\section{Appendix A}

Table A1. List of expert interviews conducted in Austria, Germany and Switzerland.

\begin{tabular}{|c|c|c|}
\hline Code & Function & Date \\
\hline AT01 & $\begin{array}{l}\text { University of Natural Resources and Life Sciences, Vienna (BOKU); } \\
\text { Institute of Meteorology }\end{array}$ & 28 June 2016 \\
\hline AT02 & $\begin{array}{c}\text { Austrian Ministry for Sustainability and Tourism (BMNT); } \\
\text { Federal Water Engineering Administration }\end{array}$ & 12 July 2016 \\
\hline AT03 & Austrian Conference on Spatial Planning (ÖROK) & 13 July 2016 \\
\hline AT04 & Austrian Institute of Economic Research (WIFO) & 15 July 2016 \\
\hline AT05 & $\begin{array}{l}\text { University of Natural Resources and Life Sciences, Vienna (BOKU); } \\
\text { Institute of Water Management, Hydrology and Hydraulic Engineering }\end{array}$ & 19 July 2016 \\
\hline AT06 & State Government of Vorarlberg; State Office for Spatial Planning & 22 September 2016 \\
\hline AT07 & State Government of Vorarlberg; State Office for Water Management & 22 September 2016 \\
\hline AT08 & State Government of Vorarlberg; State Office for Hydraulic Engineering & 23 September 2016 \\
\hline DE01 & $\begin{array}{l}\text { LUBW, Baden-Württemberg Institute for the Environment, } \\
\text { Survey and Nature Conservation }\end{array}$ & 24 May 2017 \\
\hline DE02 & Technical University Stuttgart & 30 May 2017 \\
\hline DE03 & Karlsruhe Institute of Technology & 4 July 2017 \\
\hline DE04 & $\begin{array}{l}\text { LUBW, Baden-Württemberg Institute for the Environment, } \\
\text { Survey and Nature Conservation }\end{array}$ & 4 July 2017 \\
\hline DE05 & University of Stuttgart & 5 July 2017 \\
\hline DE06 & Baden-Württemberg Ministry for Environment & 12 July 2017 \\
\hline DE07 & LfU, Bavarian State Office for the Environment & 8 August 2017 \\
\hline DE08 & LfU, Bavarian State Office for the Environment & 4 September 2017 \\
\hline DE09 & $\begin{array}{l}\text { LUBW, Baden-Württemberg Institute for the Environment, } \\
\text { Survey and Nature Conservation }\end{array}$ & 10 April 2018 \\
\hline DE10 & Technical University of Munich & 15 June 2018 \\
\hline $\mathrm{CH} 01$ & Federal Office for the Environment, Flood Protection Section & 8 June 2017 \\
\hline $\mathrm{CH} 02$ & Federal Office for the Environment, Section Risk Management Section & 8 June 2017 \\
\hline $\mathrm{CH} 03$ & Federal Office for the Environment, Hydrology Division & 8 June 2017 \\
\hline $\mathrm{CH} 04$ & University Bern, Mobiliar Lab & 9 June 2017 \\
\hline $\mathrm{CH} 05$ & Consultant in Risk Management & 9 June 2017 \\
\hline $\mathrm{CH} 06$ & Consultant in Risk Management & 19 September 2017 \\
\hline
\end{tabular}

\section{References}

1. Kundzewicz, Z.W. Climate change track in river floods in Europe. Proc. Int. Assoc. Hydrol. Sci. 2015, 369, 189-194. [CrossRef]

2. Kundzewicz, Z.W.; Lugeri, N.; Dankers, R.; Hirabayashi, Y.; Döll, P.; Pińskwar, I.; Dysarz, T.; Hochrainer, S.; Matczak, P. Assessing river flood risk and adaptation in Europe-Review of projections for the future. Mitig. Adapt. Strateg. Glob. Chang. 2010, 15, 641-656. [CrossRef] 
3. Kundzewicz, Z.W.; Krysanova, V.; Dankers, R.; Hirabayashi, Y.; Kanae, S.; Hattermann, F.F.; Huang, S.; Milly, P.C.D.; Stoffel, M.; Driessen, P.P.J.; et al. Differences in flood hazard projections in Europe-Their causes and consequences for decision making. Hydrol. Sci. J. 2017, 62, 1-14. [CrossRef]

4. Morrison, A.; Westbrook, C.J.; Noble, B.F. A review of the flood risk management governance and resilience literature. J. Flood Risk Manag. 2018, 11, 291-304. [CrossRef]

5. Tempels, B. Flood Resilience: A Co-Evolutionary Approach. Residents, Spatial Developments and Flood Risk Management in the Dender Basin; Ghent University: Ghent, Belgium, 2016.

6. Mens, M.J.P.; Klijn, F.; de Bruijn, K.M.; van Beek, E. The meaning of system robustness for flood risk management. Environ. Sci. Policy 2011, 14, 1121-1131. [CrossRef]

7. Restemeyer, B.; Brink, M.; van den Woltjer, J. Between adaptability and the urge to control: Making long-term water policies in the Netherlands. J. Environ. Plan. Manag. 2017, 60, 920-940. [CrossRef]

8. STAR-FLOOD|Towards More Resilient Flood Risk Governance. Available online: http://www.starflood.eu/ (accessed on 9 August 2019).

9. Wiering, M.; Kaufmann, M.; Mees, H.; Schellenberger, T.; Ganzevoort, W.; Hegger, D.L.T.; Larrue, C.; Matczak, P. Varieties of flood risk governance in Europe: How do countries respond to driving forces and what explains institutional change? Glob. Environ. Chang. 2017, 44, 15-26. [CrossRef]

10. Alexander, M.; Priest, S.; Mees, H. A framework for evaluating flood risk governance. Environ. Sci. Policy 2016, 64, 38-47. [CrossRef]

11. Matczak, J.; Lewandowski, J.; Chorynski, A.; Szwed, M.; Kundzewicz, Z.W. Analysing and Evaluating Flood Risk Governance in Poland: Looking for Strategic Planning in a Country in Transition; STAR-FLOOD Consortium: Poznan, Poland, 2016.

12. Ek, K.; Goytia, S.; Pettersson, M.; Spegel, E. Analysing and Evaluating Flood Risk Governance in Sweden: Adaptation to Climate Change? STAR-FLOOD Consortium: Poznan, Poland, 2016.

13. Kron, W.; Eichner, J.; Kundzewicz, Z.W. Reduction of flood risk in Europe-Reflections from a reinsurance perspective. J. Hydrol. 2019, 576, 197-209. [CrossRef]

14. Winsemius, H.C.; Aerts, J.C.J.H.; Van, B.; Bierkens, M.F.P.; Bouwman, A.; Jongman, B.; Kwadijk, J.C.J.; Ligtvoet, W.; Lucas, P.L.; Van, V.; et al. Global drivers of future river flood risk. Nat. Clim. Chang. 2016, 6, 381-385. [CrossRef]

15. Alfieri, L.; Feyen, L.; Baldassarre, G.D. Increasing flood risk under climate change: A pan-European assessment of the benefits of four adaptation strategies. Clim. Chang. 2016, 136, 507-521. [CrossRef]

16. Hogl, K.; Kvarda, E.; Nordbeck, R.; Pregernig, M. Legitimacy and effectiveness of environmental governance: Concepts and perspectives. In Environmental Governance: The Challenge of Legitimacy and Effectiveness; Hogl, K., Kvarda, E., Nordbeck, R., Pregernig, M., Eds.; Edward Elgar: Cheltenham, UK; Northampton, MA, USA, 2012; pp. 1-26.

17. Liefferink, D.; Wiering, M.; Crabbé, A.; Hegger, D. Explaining stability and change. Comparing flood risk governance in Belgium, France, the Netherlands, and Poland. J. Flood Risk Manag. 2018, 11, 281-290. [CrossRef]

18. Lange, H.; Garrelts, H. Risk Management at the Science-Policy Interface: Two Contrasting Cases in the Field of Flood Protection in Germany. J. Environ. Policy Plan. 2007, 9, 263-279. [CrossRef]

19. Mostert, E.; Pahl-Wostl, C.; Rees, Y.; Searle, B.; Tàbara, D.; Tippett, J. Social learning in European river-basin management: Barriers and fostering mechanisms from 10 river basins. Ecol. Soc. 2007, 12, 19. [CrossRef]

20. Bergsma, E. From Flood Safety to Spatial Management: Expert-Policy Interactions in Dutch and US Flood Governance; Springer: Berlin, Germany, 2018; ISBN 978-3-319-96716-5.

21. Araral, E.; Wang, Y. Water Governance 2.0: A Review and Second Generation Research Agenda. Water Resour. Manag. 2013, 27, 3945-3957. [CrossRef]

22. Hegger, D.L.T.; Driessen, P.P.J.; Dieperink, C.; Wiering, M.; Raadgever, G.T.T.; van Rijswick, H.F.M.W. Assessing Stability and Dynamics in Flood Risk Governance. Water Resour. Manag. 2014, 28, 4127-4142. [CrossRef]

23. Timmerman, J.G.; Langaas, S. Water information: What is it good for? The use of information in transboundary water management. Reg. Environ. Chang. 2005, 5, 177-187. [CrossRef]

24. Xu, Y.-P.; Tung, Y.-K. Decision-making in Water Management under Uncertainty. Water Resour. Manag. 2008, 22, 535-550. [CrossRef] 
25. Beck, S. Moving beyond the linear model of expertise? IPCC and the test of adaptation. Reg. Environ. Chang. 2011, 11, 297-306. [CrossRef]

26. Pregernig, M. Framings of science-policy interactions and their discursive and institutional effects: Examples from conservation and environmental policy. Biodivers. Conserv. 2014, 23, 3615-3639. [CrossRef]

27. Leskens, J.G.; Brugnach, M.; Hoekstra, A.Y.; Schuurmans, W. Why are decisions in flood disaster management so poorly supported by information from flood models? Environ. Model. Softw. 2014, 53, 53-61. [CrossRef]

28. Höllermann, B.; Evers, M. Perception and handling of uncertainties in water management-A study of practitioners' and scientists' perspectives on uncertainty in their daily decision-making. Environ. Sci. Policy 2017, 71, 9-18. [CrossRef]

29. Morss, R.E.; Wilhelmi, O.V.; Downton, M.W.; Gruntfest, E. Flood Risk, Uncertainty, and Scientific Information for Decision Making: Lessons from an Interdisciplinary Project. Bull. Am. Meteorol. Soc. 2005, 86, 1593-1602. [CrossRef]

30. Frick, J.; Hegg, C. Can end-users' flood management decision making be improved by information about forecast uncertainty? Atmos. Res. 2011, 100, 296-303. [CrossRef]

31. Colosimo, M.F.; Kim, H. Incorporating innovative water management science and technology into water management policy. Energy Ecol. Environ. 2016, 1, 45-53. [CrossRef]

32. Nakanishi, H.; Black, J. Implicit and explicit knowledge in flood evacuations with a case study of Takamatsu, Japan. Int. J. Disaster Risk Reduct. 2018, 28, 788-797. [CrossRef]

33. Newig, J.; Challies, E.; Jager, N.; Kochskämper, E. What Role for Public Participation in Implementing the EU Floods Directive? A Comparison with the Water Framework Directive, Early Evidence from Germany and a Research Agenda. Environ. Policy Gov. 2014, 24, 275-288. [CrossRef]

34. Newig, J.; Kochskämper, E.; Challies, E.; Jager, N.W. Exploring governance learning: How policymakers draw on evidence, experience and intuition in designing participatory flood risk planning. Environ. Sci. Policy 2015, 55, 353-360. [CrossRef]

35. Fritsch, O. Integrated and adaptive water resources management: Exploring public participation in the UK. Reg. Environ. Chang. 2017, 17, 1933-1944. [CrossRef]

36. Hedelin, B. The EU floods directive in Sweden: Opportunities for integrated and participatory flood risk planning. J. Flood Risk Manag. 2017, 10, 226-237. [CrossRef]

37. IPCC Second Assessment. Climate Change 1995. A Report of the Intergovernmental Panel on Climate Change; IPCC, Ed.; Intergovernmental Panel on Climate Change: Geneva, Switzerland, 1996; ISBN 978-0-7881-3923-9.

38. Kundzewicz, Z.W.; Kanae, S.; Seneviratne, S.I.; Handmer, J.; Nicholls, N.; Peduzzi, P.; Mechler, R.; Bouwer, L.M.; Arnell, N.; Mach, K.; et al. Flood risk and climate change: Global and regional perspectives. Hydrol. Sci. J. 2014, 59, 1-28. [CrossRef]

39. Bäckstrand, K. Scientisation vs. Civic Expertise in Environmental Governance: Eco-feminist, Eco-modern and Post-modern Responses. Environ. Politics 2004, 13, 695-714. [CrossRef]

40. Kundzewicz, Z.W.; Krysanova, V.; Benestad, R.E.; Hov, Ø.; Piniewski, M.; Otto, I.M. Uncertainty in climate change impacts on water resources. Environ. Sci. Policy 2018, 79, 1-8. [CrossRef]

41. Pregernig, M.; Böcher, M. The role of expertise in environmental governance: Theoretical perspectives and empirical evidence. In Long-Term Governance for Social-Ecological Change; Siebenhüner, B., Arnold, M., Eisenack, K., Jacob, K., Eds.; Routledge: London, UK; New York, NY, USA, 2013; pp. 29-46.

42. Hermann, A.T.; Hogl, K.; Pregernig, M. Science-policy interactions in Austrian, Dutch, and Swiss climate policy: A comparative account. J. Environ. Policy Plan. 2017, 19, 168-182. [CrossRef]

43. Pielke, R.A. When scientists politicize science: Making sense of controversy over The Skeptical Environmentalist. Environ. Sci. Policy 2004, 7, 405-417. [CrossRef]

44. Beck, U.; Bonß, W. Soziologie und Modernisierung. Zur Ortsbestimmung der Verwendungsforschung. Soz. Welt 1984, 35, 381-406.

45. Grundmann, R. The role of expertise in governance processes. For. Policy Econ. 2009, 11, 398-403. [CrossRef]

46. Weiss, C.H. Knowledge Creep and Decision Accretion. Knowl. Creat. Diffus. Util. 1980, 1, 381-404. [CrossRef]

47. Fuchs, S.; Röthlisberger, V.; Thaler, T.; Zischg, A.; Keiler, M. Natural Hazard Management from a Coevolutionary Perspective: Exposure and Policy Response in the European Alps. Ann. Am. Assoc. Geogr. 2017, 107, 382-392. [CrossRef] 
48. Witt, H. Volume Strategies in Qualitative and Quantitative Research. Forum Qualitative Sozialforschung/Forum: Qualitative Social Research; 2001; Volume 2. Available online: http://www.qualitative-research.net/index.php/ fqs/article/view/969 (accessed on 2 June 2019).

49. Gläser, J.; Laudel, G. Experteninterviews und Qualitative Inhaltsanalyse: Als Instrumente Rekonstruierender Untersuchungen, 4th ed.; VS Verlag für Sozialwissenschaften: Wiesbaden, Germany, 2010; ISBN 978-3-531-17238-5.

50. Hebenstreit, K. Auswirkungen von Klimaänderungen auf die Hydrologie Alpiner Einzugsgebiete. In Wiener Mitteilungen. Wasser, Abwassser, Gewässer; TU Wien/BOKU/ÖWAV: Wien, Austria, 2000; Volume 160.

51. Nachtnebel, H.; Fuchs, M. Beurteilung der hydrologischen Veränderungen in Österreich infolge globaler Klimaänderungen. Österr. Wasser Abfallwirtsch. 2004, 7-8, 79-92.

52. Godina, R. Veränderungen in hydrologischen Zeitreihen. In Auswirkungen des Klimawandels auf Hydrologie und Wasserwirtschaftin Österreich; ÖWAV, Ed.; Österreichischer Wasser-und Abfallwirtschaftsverband: Wien, Austria, 2010; pp. 35-49.

53. Blöschl, G.; Merz, B. Bestimmung von Bemessungshochwässern gegebener Jährlichkeit-Aspekte einer zeitgemäßen Strategie. Wasserwirtschaft 2008, 11, 12-18.

54. Blöschl, G.; Blaschke, A.P.; Haslinger, K.; Hofstätter, M.; Parajka, J.; Salinas, J.; Schöner, W. Auswirkungen der Klimaänderung auf Österreichs Wasserwirtschaft-Ein aktualisierter Statusbericht. Österr. Wasser Abfallwirtsch. 2018, 70, 462-473. [CrossRef]

55. Formayer, H.; Kromp-Kolb, H. Hochwasser und Klimawandel. Auswirkungen des Klimawandels auf Hochwasserereignisse in Österreich (Endbericht WWF 2006). BOKU-Met. Report 7; University of Natural Resources and Life Sciences: Vienna, Austria, 2009.

56. Formayer, H.; Kromp-Kolb, H.; Schwarzl, I. Auswirkungen des Klimawandels auf Hochwasserereignisse in Oberösterreich. BOKU-MET Report 14; Universität für Bodenkultur Wien: Wien, Austria, 2009.

57. Blöschl, G.; Viglione, A.; Heindl, H. Dynamik von Hochwasserbemessungsgrößen und Konsequenzen-Klimawandel. FloodRisk II, Teilprojekt 6.2; Bundesministerium für Land-und Forstwirtschaft, Umwelt und Wasserwirtschaft (BMLFUW): Wien, Austria, 2008.

58. Nachtnebel, H. Auswirkungen von möglichen Klimaänderungen auf die Hydrologie und Wasserwirtschaft in einigen österreichischen Regionen. In Auswirkungen des Klimawandels auf Die Österreichische Wasserwirtschaft; BMLFUW, ÖWAV, Eds.; Bundesministerium für Land-und Forstwirtschaft, Umwelt und Wasserwirtschaft: Wien, Austria, 2008.

59. Holzmann, H.; Lehmann, T.; Formayer, H.; Haas, P. Auswirkungen möglicher Klimaänderungen auf Hochwasser und Wasserhaushaltskomponenten ausgewählter Einzugsgebiete in Österreich. Österr. Wasser Abfallwirtsch. 2010, 62, 7-14. [CrossRef]

60. Nachtnebel, H.; Stanzel, P. Auswirkungen von möglichen Klimaänderungen auf den Wasserhaushalt und Extremwerte. In Auswirkungen des Klimawandels auf Hydrologie und Wasserwirtschaft in Österreich; ÖWAV, Ed.; Österreichischer Wasser- und Abfallwirtschaftsverband: Wien, Austria, 2010.

61. Anpassungsstrategien an den Klimawandel für Österreichs Wasserwirtschaft; ZAMG/TU WIEN, Ed.; Bundesministerium für Land-und Forstwirtschaft, Umwelt und Wasserwirtschaft: Wien, Austria, 2010.

62. Blöschl, G.; Viglione, A.; Merz, R.; Parajka, J.; Salinas, J.L.; Schöner, W. Auswirkungen des Klimawandels auf Hochwasser und Niederwasser. Österr. Wasser Abfallwirtsch. 2011, 63, 21-30. [CrossRef]

63. Auswirkungen des Klimawandels auf Hydrologie und Wasserwirtschaft in Österreich. Präsentation der aktuellen Studien; ÖWAV, Ed.; Österreichischer Wasser-und Abfallwirtschaftsverband: Wien, Austria, 2010.

64. Klimawandelauswirkungen und Anpassungsstrategien in der Österreichischen Wasserwirtschaft. ÖWAV-ExpertInnenpapier; ÖWAV, Ed.; Österreichischer Wasser-und Abfallwirtschaftsverband: Wien, Austria, 2014.

65. Hochwasserschutz in Österreich. Flood protection in Austria; BMLFUW, Ed.; Bundesministerium für Land- und Forstwirtschaft, Umwelt und Wasserwirtschaft: Wien, Austria, 2006.

66. The Austrian Strategy for Adaptation to Climate Change; BMLFUW, Ed.; Bundesministerium für Land- und Forstwirtschaft, Umwelt und Wasserwirtschaft: Vienna, Austria, 2012.

67. APCC. Österreichischer Sachstandsbericht Klimawandel 2014 (AAR14); Austrian Panel on Climate Change; Verlag der Österreichischen Akademie der Wissenschaften: Wien, Austria, 2014; ISBN 978-3-7001-7699-2.

68. Nationaler Hochwasserrisikomanagementplan 2015; BMLFUW, Ed.; Bundesministerium für Land- und Forstwirtschaft, Umwelt und Wasserwirtschaft: Wien, Austria, 2016. 
69. Flood Risk Management in Austria. Objectives-Measures-Good Practice; BMNT, Ed.; Austrian Federal Ministry for Sustainability and Tourism: Vienna, Austria, 2018.

70. Thieken, A.H.; Cammerer, H.; Dobler, C.; Lammel, J.; Schöberl, F. Estimating changes in flood risks and benefits of non-structural adaptation strategies-A case study from Tyrol, Austria. Mitig. Adapt. Strateg. Glob. Chang. 2016, 21, 343-376. [CrossRef]

71. Löschner, L.; Herrnegger, M.; Apperl, B.; Senoner, T.; Seher, W.; Nachtnebel, H.P. Flood risk, climate change and settlement development: A micro-scale assessment of Austrian municipalities. Reg. Environ. Chang. 2017, 17, 311-322. [CrossRef]

72. Bárdossy, A.; Caspary, H.J. Detection of climate change in Europe by analyzing European atmospheric circulation patterns from 1881 to 1989. Theor. Appl. Climatol. 1990, 42, 155-167. [CrossRef]

73. Caspary, H.J.; Bárdossy, A. Markieren die Winterhochwasser 1990 und 1993 das Ende der Stationarität in der Hochwasserhydrologie infolge von Klimaänderungen? Wasser Boden 1995, 47, 18-24.

74. KLIWA. 2. KLIWA-Symposium: Am 03. und 04.05.2004 in Würzburg: Fachvorträge Klimaveränderung und Konsequenzen für Die Wasserwirtschaft; Klimaveränderung und Wasserwirtschaft: München, Germany, 2004; p. 249.

75. Dankers, R.; Feyen, L. Climate change impact on flood hazard in Europe: An assessment based on high-resolution climate simulations. J. Geophys. Res. 2008, 113. [CrossRef]

76. Madsen, H.; Lawrence, D.; Lang, M.; Martinkova, M.; Kjeldsen, T.R. Review of trend analysis and climate change projections of extreme precipitation and floods in Europe. J. Hydrol. 2014, 519, 3634-3650. [CrossRef]

77. Bronstert, A.; Bormann, H.; Bürger, G.; Haberlandt, U.; Hattermann, F.; Heistermann, M.; Huang, S.; Kolokotronis, V.; Kundzewicz, Z.; Menzel, L.; et al. Hochwasser und Sturzfluten an Flüssen in Deutschland. In Klimawandel in Deutschland: Entwicklung, Folgen, Risiken und Perspektiven; Brasseur, G., Jacob, D., Schuck-Zöller, S., Eds.; Springer Spektrum: Berlin, Germany, 2017; pp. 87-102, ISBN 978-3-662-50396-6.

78. Bayerisches Landesamt für Umwelt; KLIWA. Kurzbericht "Der Klimawandel in Bayern für den Zeitraum 2021-2050" (Kenntnisstand Januar 2005); KLIWA: Münster, Germany, 2005; p. 14.

79. KLIWA. Regionale Klimaszenarien für Süddeutschland: Abschätzung der Auswirkungen auf den Wasserhaushalt; KLIWA: München, Germany, 2006; p. 93.

80. Hennegriff, W.; Kolokotronis, V. Methodik zur Ableitung von Klimaänderungsfaktoren für Hochwasserkennwerte in Baden-Württemberg. WasserWirtschaft 2007, 9, 31-35.

81. KLIWA. 4. KLIWA-Symposium am 3. und 4. Dezember 2009 in Mainz. Fachvorträge Klimaveränderung und Konsequenzen für Die Wasserwirtschaft; Klimaveränderung und Wasserwirtschaft: Karlsruhe, Germany, 2010.

82. KLIWA. 5. KLIWA-Symposium am 6. und 7. Dezember 2012 in Würzburg. Fachvorträge Klimaveränderung und Konsequenzen für Die Wasserwirtschaft; KLIWA: Kasendorf, Germany, 2013; p. 258.

83. KLIWA. 6. KLIWA-Symposium am 22. und 23. Mai 2017 in Baden-Baden. Fachvorträge Risiko Klima—Herausforderungen Managen; Klimaveränderung und Wasserwirtschaft: Baden-Baden, Germany, 2018; p. 278.

84. KLIWA. Klimawandel in Süddeutschland. Veränderung der Kenngrößen Lufttemperatur, Niederschlag und Hochwasserabfluss, Klimamonitoring im Rahmen des Kooperationsvorhabens KLIWA. Monitoringbericht 2008; KLIWA: Münster, Germany, 2008; p. 24.

85. KLIWA. Klimawandel in Süddeutschland, Veränderungen von Meteorologischen und Hydrologischen Kenngrößen, Klimamonitoring im Rahmen des Kooperationsvorhabens KLIWA. Monitoringbericht 2011; KLIWA: Münster, Germany, 2012; p. 40.

86. KLIWA. Klimawandel in Süddeutschland Veränderungen von Meteorologischen und Hydrologischen Kenngrößen. Klimamonitoring im Rahmen der Kooperation KLIWA. Monitoringbericht 2016; KLIWA: Münster, Germany, 2017; p. 60 .

87. Magel, H.; Franke, S. Zukunftsstrategien im Ländlichen Raum für die Bayerische Wasserwirtschaftsverwaltung im Lichte von Good Governance; Technische Universität München: München, Germany, 2008; p. 205.

88. Hattermann, F.F.; Huang, S.; Burghoff, O.; Willems, W.; Österle, H.; Büchner, M.; Kundzewicz, Z. Modelling flood damages under climate change conditions-A case study for Germany. Nat. Hazards Earth Syst. Sci. 2014, 14, 3151-3168. [CrossRef] 
89. Koch, M.; Hennegriff, W.; Moser, M.; Groteklaes, M.; Krause, L.; Röder, S.; Gosch, L.; Weinbrenner, D.; Cassel, M.; Wilkinson, K.; et al. Leitfaden Kommunales Starkregenrisikomanagement in Baden-Württemberg; LUBW Landesanstalt für Umwelt, Messungen und Naturschutz Baden-Württemberg, Ed.; LUBW Landesanstalt für Umwelt, Messungen und Naturschutz Baden-Württemberg: Karlsruhe, Germany, 2016; ISBN 978-3-88251-391-2.

90. KLIWA. KLIWA-Symposium vom 29. und 30.11.2000 in Karlsruhe; KLIWA: Münster, Germany, 2000; p. 276.

91. KLIWA. Über KLIWA. Available online: https://www.kliwa.de/kliwa.htm (accessed on 2 June 2019).

92. Landesanstalt für Umwelt Messungen und Naturschutz Baden-Württemberg. Climate Change in Southern Germany. Challenges-Adaptation. Consequences for Water Management; Klimaveränderung und Wasserwirtschaft: Karlsruhe, Germany, 2017; p. 12.

93. Landesanstalt für Umweltschutz Baden-Württemberg. Festlegung des Bemessungshochwassers für Anlagen des technischen Hochwasserschutzes_Leitfaden; 1; Landesanstalt für Umweltschutz Baden-Württemberg: Mannheim, Germany, 2005; ISBN 3-88251-288-1.

94. Bayerisches Staatsministerium für Umwelt und Gesundheit. Berücksichtigung von Klimaänderungen; Bemessung von Hochwasserschutzeinrichtungen; Gesetz Nr. 7535-UG.; StMUV: Munich, Germany, 2009.

95. Rutschmann, P.; Asenkerschbaumer, M.; Skublics, D. Verzögerung und Abschätzung von Hochwasserwellen entlang der bayerischen Donau. Abschlussbericht 2012; Technische Universität München: München, Germany, 2012; p. 166.

96. Rutschmann, P.; Giehl, S.; Skublics, D.; Scandroglio, R. Vertiefte Wirkungsanalyse zu: “Verzögerung und Abschätzung von Hochwasserwellen Entlang der Bayerischen Donau". Schlussbericht Teil I; Technische Universität München: München, Germany, 2017; p. 195.

97. Rutschmann, P.; Skublics, D.; Giehl, S. Vertiefte Wirkungsanalyse zu: "Verzögerung und Abschätzung von Hochwasserwellen Entlang der bayerischen Donau". Zwischenbericht; Technische Universität München: München, Germany, 2014; p. 81.

98. Pfister, C. Die "Katastrophenlücke" des 20. Jahrhunderts und der Verlust traditionalen Risikobewusstseins. GAIA-Ecol. Perspect. Sci. Soc. 2009, 18, 239-246.

99. Andres, A.; Badoux, A. The Swiss flood and landslide damage database: Normalisation and trends. J. Flood Risk Manag. 2018. [CrossRef]

100. Spreafico, M.; Stadler, K. Hochwasserabflüsse in Schweizerischen Gewässern. Landeshydrologie und-geologie 1988, 7, 17-25.

101. Frei, C.; Davies, H.C.; Gurtz, J.; Schär, C. Climate dynamics and extreme precipitation and flood events in Central Europe. Integr. Assess. 2000, 1, 281-300. [CrossRef]

102. Extreme Events and Climate Change; OcCC, Ed.; Organe Consultatif sur les Changements Climatiques: Berne, Switzerland, 2003.

103. Climate Change and Switzerland 2050. Expected Impacts on Environment, Society and Economy; OcCC, ProClim, Eds.; OcCC/ProClim: Bern, Switzerland, 2007.

104. Schmocker-Fackel, P.; Naef, F. More frequent flooding? Changes in flood frequency in Switzerland since 1850. J. Hydrol. 2010, 381, 1-8. [CrossRef]

105. Schmocker-Fackel, P.; Naef, F. Changes in flood frequencies in Switzerland since 1500. Hydrol. Earth Syst. Sci. 2010, 14, 1581-1594. [CrossRef]

106. CH2011; C2SM, MeteoSwiss, ETH, NCCR Climate, OcCC, Eds.; Swiss Climate Change Scenarios CH2011: Zurich, Switzerland, 2011.

107. CH2014-Impacts. Toward Quantitative Scenarios of Climate Change Impacts in Switzerland; OCCR, BAFU, MeteoSwiss, C2SM, Agroscope, ProClim: Bern, Switzerland, 2014.

108. Köplin, N.; Schädler, B.; Viviroli, D.; Weingartner, R. Seasonality and magnitude of floods in Switzerland under future climate change. Hydrol. Process. 2014, 28, 2567-2578. [CrossRef]

109. Beniston, M.; Stoffel, M. Rain-on-snow events, floods and climate change in the Alps: Events may increase with warming up to $4{ }^{\circ} \mathrm{C}$ and decrease thereafter. Sci. Total Environ. 2016, 571, 228-236. [CrossRef]

110. Brennpunkt Klima Schweiz Grundlagen, Folgen und Perspektiven; Akademien der Wissenschaften Schweiz, Ed.; Akademien der Wissenschaften Schweiz: Bern, Switzerland, 2016. 
111. CH2018 - Climate Scenarios for Switzerland. Technical Report; National Centre for Climate Services: Zurich, Switzerland, 2018.

112. Summermatter, S. Die instrumentalisierte Katastrophe: Die Schweizer Wasserbaupolitik vor und nach den Überschwemmungen von 1868. Hist. Soc. Res. 2007, 32, 200-214.

113. Hochwasser 2005 in der Schweiz. Synthesebericht zur Ereignisanalyse; BAFU, Ed.; Bundesamt für Umwelt BAFU: Bern, Switzerland, 2008.

114. Boosting Disaster Prevention through Innovative Risk Governance. Insights from Austria, France and Switzerland; OECD, Ed.; OECD Publishing: Paris, France, 2017.

115. FAN. Fachleute Naturgefahren Schweiz. Available online: http://www.fan-info.ch/ (accessed on 9 May 2019).

116. Von der Gefahrenabwehr zur Risikokultur; PLANAT (Ed.) National Platform for Natural Hazards (PLANAT), Bundesamt für Umwelt (BAFU), Bundesamt für Raumplanung (ARE): Berne, Switzerland, 1998.

117. PLANAT. Sicherheit vor Naturgefahren. Vision und Strategie; PLANAT Reihe 1/2004; Nationale Plattform Naturgefahren PLANAT: Biel, Switzerland, 2004.

118. PLANAT. Management of Risks from Natural Hazards. Strategy 2018; Platform on Natural Hazards of the Alpine Convention PLANALP: Biel, Switzerland, 2018.

119. Risikobasierte Raumplanung: Synthesebericht zu zwei Testplanungen auf Stufe Kommunaler Nutzungsplanung; PLANAT, ARE, BAFU: Berne, Switzerland, 2014.

120. FOWG. Flood Control at Rivers and Streams. Guidelines of the FOWG; Federal Office for Water and Geology: Berne, Switzerland, 2001.

121. Umgang mit Naturgefahren in der Schweiz. Bericht des Bundesrats in Erfüllung des Postulats 12.4271 Darbellay vom 14.12.2012; BAFU, Ed.; Bundesamt für Umwelt BAFU: Bern, Switzerland, 2016.

122. Anpassung an den Klimawandel in der Schweiz. Ziele, Herausforderungen und Handlungsfelder. Erster Teil der Strategie des Bundesrates vom 2. März 2012; BAFU, Ed.; Bundesamt für Umwelt BAFU: Bern, Switzerland, 2012.

123. Klimabedingte Risiken und Chancen. Eine schweizweite Synthese; BAFU, Ed.; Bundesamt für Umwelt BAFU: Bern, Switzerland, 2017.

124. PLANAT. Strategie 2018 "Umgang mit Risiken aus Naturgefahren"; Platform on Natural Hazards of the Alpine Convention PLANALP: Biel, Switzerland, 2018.

125. OECD. Financial Management of Flood Risk; OECD Publishing: Paris, France, 2016.

126. Zaugg, M. Philosophiewandel im Schweizerischen Wasserbau: Zur Vollzugspraxis des Nachhaltigen Hochwasserschutzes. Ph.D. Thesis, Universität Zürich, Zürich, Switzerland, 2006.

127. Leitsätze zum Hochwasserschutz und zur Revitalisierung an Fliessgewässern; BAFU, Ed.; Bundesamt für Umwelt BAFU: Bern, Switzerland, 2015.

128. Living with Natural Hazards. Objectives and Priorities for Action of the Federal Office for the Environment (FOEN) in Dealing with Natural Hazards; BAFU, Ed.; Federal Office for the Environment: Berne, Switzerland, 2011.

129. Impulse für eine klimaangepasste Schweiz. Erkenntnisse aus 31 Pilotprojekten zur Anpassung an den Klimawandel; BAFU, Ed.; Bundesamt für Umwelt BAFU: Bern, Switzerland, 2017.

130. Widmer, A. Mainstreaming climate adaptation in Switzerland: How the national adaptation strategy is implemented differently across sectors. Environ. Sci. Policy 2018, 82, 71-78. [CrossRef]

131. Strassheim, H.; Kettunen, P. When does evidence-based policy turn into policy-based evidence? Configurations, contexts and mechanisms. Evid. Policy 2014, 10, 259-277. [CrossRef]

132. Van Enst, W.I.; Driessen, P.P.J.; Runhaar, H.A.C. Towards productive science-policy interfaces: A research agenda. J. Environ. Assmt. Policy Manag. 2014, 16, 1450007. [CrossRef]

133. Halffman, W.; Hoppe, R. Science/Policy Boundaries: A Changing Division of Labour in Dutch Expert Policy Advice. In Democratization of Expertise? Exploring Novel Forms of Scientific Advice in Political Decision-Making; Maasen, S., Weingart, P., Eds.; Sociology of the Science Yearbook-Vol. 24; Springer: Dordrecht, The Netherlands, 2005; pp. 135-151.

134. Brand, U.; Pawloff, A. Selectivities at Work: Climate Concerns in the Midst of Corporatist Interests. The Case of Austria. J. Environ. Prot. 2014, 5, 780-795. [CrossRef] 
135. Hermann, A.T.; Pregernig, M.; Hogl, K.; Bauer, A. Cultural Imprints on Scientific Policy Advice: Climate science-policy interactions within Austrian neo-corporatism. Environ. Policy Gov. 2015, 25, 343-355. [CrossRef]

136. Protection against Natural Hazards. Vision and Strategy (Englisch Summary); Nationale Plattform Naturgefahren PLANAT: Biel, Switzerland, 2004. 